The Government of Life 
This page intentionally left blank 


\section{forms of living}

Stefanos Geroulanos and Todd Meyers, series editors 
This page intentionally left blank 


\section{The Government of Life}

Foucault, Biopolitics, and Neoliberalism

Edited by Vanessa Lemm and Miguel Vatter

F O R D H M U N IVERS I T P RES S

NEW YORK 2 O I 4 
Copyright (C) 2014 Fordham University Press

All rights reserved. No part of this publication may be reproduced, stored in a retrieval system, or transmitted in any form or by any means-electronic, mechanical, photocopy, recording, or any other-except for brief quotations in printed reviews, without the prior permission of the publisher.

Fordham University Press has no responsibility for the persistence or accuracy of URLs for external or third-party Internet websites referred to in this publication and does not guarantee that any content on such websites is, or will remain, accurate or appropriate.

Fordham University Press also publishes its books in a variety of electronic formats. Some content that appears in print may not be available in electronic books.

Library of Congress Cataloging-in-Publication Data is available from the publisher.

Printed in the United States of America

$\begin{array}{llllllll}\text { I6 } & \text { I5 I4 } & 54 & 4 & 2 & \text { I }\end{array}$

First edition 